\title{
Identifying and Overcoming Cognitive Fixation in Pastoral Decision-Making
}

\author{
Hector Ramos* and Joyce Juntune \\ Department of Educational Psychology, Texas A\&M University, College Station, USA \\ Email of corresponding author: hreina@tamu.edu
}

\begin{abstract}
This qualitative study examined cognitive fixation in protestant pastoral decision-making. The participants included ten Protestant pastors from different churches in central Texas. Pastors chosen for this study led congregations consisting of a minimum of 50 members and a maximum of 1800 members, and had served in a full-time pastoral position for at least five years and not more than 28 years. Through naturalistic inquiry, data were obtained from face-to-face interviews and observations. A constant comparative method and thematic analysis were used to analyze the data for emergent themes. Three themes emerged: 1) cognitive fixation in pastoral decision-making involves more areas than just the pastor, and is heavily influenced by the concepts of clergy and laity, 2) cognitive fixation plays a role in how pastors perceive challenges and 3) special circumstances may have helped many pastors overcome cognitive fixation. The data revealed the complexity of cognitive fixation in pastoral decision-making. It was seen to take place in interactions amongst pastors, church structures and traditions, lay leaders and congregations. Cognitive fixation that happens at the leader or congregational level has an effect on pastoral decision making.
\end{abstract}

Keywords: Cognitive Fixation; Creative Cognition; Flexibility; Leadership.

\section{INTRODUCTION}

Could cognitive fixation be one of the obstacles preventing pastors from being responsive to the ever-changing demands of society? Some researchers have argued for pastors to become more aware of their thought processes in order to better meet the changing needs of their congregations and society (Kinnaman, 2011; The Barna Group, 2006). Previous studies on cognitive fixation have included populations such as engineering faculty (Linsey, Tseng, Wood, Schunn, Fu, \& Cagan, 2010), engineering students (Jansson \& Smith, 1991; Viswanathan \& Linsey, 2013), expert tax practitioners (Dearman \& Shields, 2005; Marchant, Robinson, Anderson, \& Schadewald, 1991), physicians (Graber, Franklin, \& Gordon, 2005), and expert programmers (Adelson, 1984). If cognitive fixation limits decision-making in these fields, one might wonder if and how cognitive fixation limits the decisionmaking of pastors. This study provides a possible answer by exploring the existence of cognitive fixation in pastors' thought processes.

\section{DEFINING COGNITIVE FIXATION}

Cognitive fixation is most often studied within the field of creative cognition in psychology, due to its association with mental operations (Ward, Smith, \& Vaid, 1997). The literature on cognitive fixation uses varied terminology to describe the phenomenon, employing terms such as functional fixedness, mental set, and groupthink. When cognitive fixation is discussed with respect to the use of objects, it is commonly referred to as functional fixedness. Functional fixedness occurs when a person is unable to use an object in an original way to solve a problem, and instead continues to see it only in its traditional role. This relates to preconceived notions regarding the use of such objects that prevent the user from discovering non-traditional and more creative uses (Purcell \& Gero, 1996).

Cognitive fixation is referred to as "mental set" in the business world. It is a mental predisposition to solve problems in a certain way, even though easier and more effective solutions may be available. In one study, participants were given a series similar challenges; in response, they designed a formula to solve the larger problem. When certain underlying aspects of the challenge changed, these participants continued to use their formula instead of finding more effective solutions; they believed their formula would continue to be effective (Vallée-Tourangeau, Euden, \& Hearn, 2011; Luchins \& Luchins, 1959).

Groupthink shares some of the elements of cognitive fixation. It occurs when a group's 
dynamics influence its members such that they fixate on the leader's ideas without first looking into possible alternatives. For instance, this may happen when the leader is particularly charismatic (Janis, 1972). A group is most vulnerable when it is protected from outside opinions and group members share similar backgrounds and experiences. (Janis, 1972).

Whether cognitive fixation is studied in psychology, engineering, medicine, or business, there are three shared elements that consistently appear: mental automaticity, blocks, and stagnation. In mental automaticity, individuals are unable to break from traditional patterns of thinking and problem solving, even when the underlying elements of the problem change (Bilalić, McLeod, \& Gobet, 2010; Luchins, 1942). Though this state of being mired in a particular problem-solving approach is a very specific form of fixation, the term is also more generally applied to inhibitions blocking creative thinking and problem solving (Smith \& Blankenship, 1991). The second element of cognitive fixation is the "mental block," an impediment to reaching the goal of a cerebral activity or operation. In this case, participants are presented with an example, but find it difficult to produce ideas beyond variations on the example given (Smith, Linsey, \& Kerne, 2010). The third element of cognitive fixation is mental stagnation, which is influenced by prior knowledge and expertise (Wiley, 1998; Hinds, 1999; Hinds, Patterson, \& Pfeffer, 2001; Smith, 2003). This occurs when the ideas that emerge are only those available within the range of the person's expertise or recent experiences, thereby limiting the number of recognizable alternatives (Chrysikou \& Weisberg, 2005).

Scholars have argued that cognitive fixation impacts creativity and the consideration of alternatives by limiting the number of choices made while thinking (Chrysikou \& Weisberg, 2005). Although there are many definitions of cognitive fixation in the literature, they all share the following common elements: mental blocks (Smith \& Linsey, 2011), the inability to produce alternatives when facing a challenge (Youmans \& Arciszewski, 2012), and determining that there can be only one solution to a problem (Bilalić et al., 2010). Therefore, the definition of cognitive fixation used in this study was the cognitive inability to produce more than one solution to a challenge, thus preventing the exploration of further alternatives.

\section{Factors Contributing to Cognitive Fixation in Individuals}

The literature suggests that expertise (Bilalić, McLeod, \& Gobet, 2008; Wiley, 1998), automaticity (Öllinger, Jones, \& Knowblich, 2008; Smith, 2003; Luchins, 1942), and sometimes age (Rhodes, 2004; Verhaeghen, Marcoen, \& Goossens, 1993) are usually factors in individual cognitive fixation. Various studies (Öllinger et al., 2008; Croskerry, 2002) have shown that expertise may act as a fixating factor in problem solving. In the cases evaluated by these researchers, expertise made learning a new procedure or approach more difficult because automatic "expert" behaviors had already been established for the same tasks. Novices tended to learn faster because they did not have the level of automaticity that expertise requires (Wiley, 1998). Wiley's experiment suggests that the influence of domain knowledge may be harmful when the task requires remote associations that need to be considered in novel ways. In Wiley's experiment, participants with more baseball knowledge obtained lower results than novices when their baseball knowledge suggested alternative solutions. More knowledge led them to greater levels of fixation, hindering them from making the appropriate associations.

Research in other domains has produced similar findings. Chess experts' recall of randomized chess boards tends to be worse than non-experts when performing the same types of exercises (Chase \& Simon, 1973). It is also well documented that doctors give more accurate diagnoses than do thirdyear interns; however, they perform at a lower level when recognizing or remembering the information they were given to make those decisions (Patel \& Groen, 1991). In a different domain, experienced accountants were found to perform at a lower level than novices when adapting to new tax law. These experts failed to consider new information because of the blocks created by their previous knowledge (Marchant et al., 1991).

The automaticity of mental sets is also a factor contributing to individual cognitive fixation. This happens when repeatedly solving a problem in the same way blocks the perception of changes in the problem's structure that might require different and more effective solutions (Öllinger et al., 2008; 
Smith, 2003; Luchins, 1942). This type of problem, also called an algorithmic problem, requires the same type of thinking every time the problem is faced (Puccio, Murdock, \& Mance, 2010). For instance, cooking pasta or changing a flat tire requires the application of a single formula or procedure that has been tested and proven effective. Problems that are routinely solved with a proven procedure create a way of thinking that automatically seeks whatever formula has already proven successful. A common example of automaticity is found in the health sector. Physicians often have cognitive fixation to blame for their mental errors. For instance, studies have found that physicians tend not to be good judges of their own performance. They often form opinions solely on the basis of early information, and show a reluctance to change those opinions when given new and important data (Redelmeier, Ferris, Tu, Hux, \& Schull, 2001). Cognitive errors in diagnosis have been attributed in large part to a failure to consider alternatives after an initial diagnosis is reached (Graber et al., 2005). The clinician's prior beliefs and expectations lead to an inadequate selection of pertinent data that results in the misdirection of subsequent reasoning and problem solving (Croskerry, 2002).

Age has also been determined to be a factor in perseverative errors; an example can be seen in participants asked to use the Wisconsin Card Sorting Test (WCST) (Rhodes, 2004), which requires participants to infer the rules of the game as participants play it. A meta-analytic review of the WCST suggests that differences in the number of errors made are largely caused by a decline in working memory (Verhaeghen et al., 1993).

\section{Cognitive Fixation in Groups}

The existing research on cognitive fixation that most closely relates to group church settings deals with "groupthink" (Primeaux, 1997). Groupthink is defined as group behavior that ignores alternatives because of collective pressure, leading to a deterioration of mental efficiency and reality testing (Janis, 1972). An example of groupthink might be if a pastor, in response to economic constraints, encourages a congregation to consider alternatives for an upcoming Christmas celebration, but influential lay leaders insist that the program not change from the expensive, traditional manner in which it had previously been conducted. Under this pressure, the congregation agrees with the influential lay leaders and succumbs to the program being done in the traditional manner, despite the need for a less expensive alternative.

Rosander, Granström, and Stiwne (2006) understood groupthink to be based on a developed framework called the bipolar groupthink model (Granström \& Stiwne, 1998). This bipolar model synthesizes Janis's (1972) groupthink characteristics into two groups: omnipotent and depressive. In omnipotent groupthink, members perceive themselves as morally superior and consider others outside the group as incapable of contributing valuable work. Members of depressive groups feel inadequate and powerless because authority is located outside the group. Rosander and associates (2006) researched three religious' groups: the Jesus Movement, teamworkbased Lutheran groups, and bureaucratic Lutheran groups. Their research suggests that less-structured religious organizations tend to be at greater risk of omnipotent groupthink, whereas highly structured religious organizations more often experience depressive groupthink. Other studies have examined the existence of powerful and influential inner circles in the church (Hougland \& Wood, 1979); one conducted a survey on ministry and bias involving protestant pastors (Nauta, 1988).

Some research has discussed the presence of cognitive fixation with charismatic and transformational leadership in small African American churches. Cognitive fixation occurs when pastors' perceptions of their role and strength of their personalities- especially in American megachurches- influence the decisions made concerning community involvement (Barnes, 2011; Alex-Assensoh, 2004; Nauss, 1995). Other research has investigated the influence of bias in ministry by conducting a survey of 382 protestant pastors. This study incorporated four scenarios that included both positive and negative experiences. An example of a negative experience was a comment from a congregant expressing dissatisfaction after a pastor's ministry visit. The results showed that pastors tended to associate positive experiences in the church with their own internal factors, while negative experiences were linked to external factors; the result was selfenhancement and self-protection (Nauta, 1988). Nauta argued that the attribution of negative experience to an external factor may be influenced by a pastor's concerns regarding public loss of social stature. 
The Barna Group (2006) shed light on cognitive fixation in the church, describing it as a misalignment between the pastors' views of the congregants' life goals, and the congregants' actual priorities. A survey was conducted of 617 pastors, querying them on their perceptions of their congregants. The results showed that pastors believed $70 \%$ of the adults attending their churches placed God as their top priority. When the same survey was given to 1,002 congregants, the results revealed that only $15 \%$ of the congregants placed God as their top priority (The Barna Group, 2006).

A United States Congregational Life Survey conducted by the National Opinion Research Center (NORC) has suggested that a type of cognitive fixation can be seen in pastors' and congregants' views on shared leadership (Carroll, 2006). The study focused on the pastors' empowerment level, and specifically on their ability to inspire members to lead ministries rather than remain wholly in charge. Out of the 434 congregations surveyed, researchers identified 351 congregations in which both the pastors and their congregations participated in the survey. Researchers then conducted a 45-minute telephone interview with each of the 351 pastors and compared their results against the survey data of the associated 351 congregants. The results showed that pastors ranked themselves at an empowerment level of $75 \%$ and at a "take charge" level of $4 \%$. The laity's view on their pastors represented the opposite perception; pastors were ranked at an empowerment level of $50 \%$, with a "take charge" level of $20 \% .3$

The existence of cognitive fixation in church settings may explain some of the challenges faced by today's houses of worship, such as perceptions of irrelevancy by potential congregants. Current statistics show that close to $60 \%$ of young people who went to church as teens stopped attending after high school. Some of the reasons reported by the millennial generation include seeing religious organizations as overprotective, repressive, and exclusive (Evans, 2013; Kinnaman, 2011), indicating a misalignment between what these young people were looking for and what the church actually provided.

\section{Overcoming Cognitive Fixation}

Recent studies (de Villiers, 2013; Kaiser, 2011) on decision-making in the church have suggested that ecclesiastical administration should return to biblical foundations. These foundations include using elders in the decision-making process and determining their number and role according to their spiritual gifts (Nehrbass, 2011). Johnson suggested that the New Testament offers a way of testing the validity of scriptures through leadership and a congregation of faith. He also introduces the work of the Spirit, present in the New Testament, as a way of overcoming sources of fixation:

When bylaws and customs, or codes and unreflected Scripture citations replace the testing of the Spirit in the church, or, more tragically, when the church proceeds on the assumption that there is no work of the Spirit to be tested, then the church may reveal itself in the process of reaching [a] decision, but it won't be as a community of faith in the Spirit (138) (Johnson, 1996).

References to the work of the Spirit can be found in the book of Acts, when Peter gives testimony about what God did at the Cornelius' house. He describes a vision given by God, a timely invitation from servants in the Cornelius' house, and his witnessing of the Holy Spirit that filled the gentiles in the same way the Spirit did with the Jews earlier on in an upper room. It came as a great surprise to the faithful Jews that the gentiles, too, could benefit from the gospel (Acts 10).

Over the last 40 years, only a few studies have examined what it takes to make a successful church (Dever, 2004; Schwartz, 2003; Macchia, 1999; Callahan, 1983). This body of research covers many different topics, ranging from the biblical understanding of leadership (Dever, 2004) and servant leadership development (Macchia, 1999), to functional structures (Schwartz, 2003) and pastoral and lay visitation (Callahan, 1983). However, Kaiser (2011) offered a different approach, based on the New Testament. This method focuses on three key components of decision-making in a successful church. Breaking away from previous paradigms, Kaiser focused on the basics, such as: 1) communicating the Word of God, and 2) being led by the Spirit of God to 3) fulfill God's mission. Kaiser created a questioning schema that can be helpful in understanding the different layers of church activity and how they build upon one another. He utilized a series of 
questions, beginning with: "Has the congregation been growing numerically?" and ending with: "Has this growing, evangelistic, reproducing, globally missional, biblically faithful congregation been seeking the face of God in all that it does?"

Other church leaders have gone beyond these parameters in their effort to see the church transform the community. They have argued that the purpose and success of a church is not found in the number of members, size of its staff, or amount of its budget, but rather on the level of transformation that can be seen in the community the church serves (Pope, 2006). This includes a transformation in the seven spheres of influence in society: politics, education, media, family, business, arts and entertainment, and religion. The purpose of the church (according to these religious leaders) is to transform society such that it is empowered and shaped by God's principles and power (Wallnau \& Johnson, 2013).

Another alternative to developing group decision-making in the church is congregational discernment. In congregational discernment, groups are facilitated through a session of silence and prayer before engaging in dialogue leading to decision-making. This practice has helped assemblies focus on what is relevant, listen deeply to one another, and enhance consensus when reaching decisions (Frykholm, Churches, \& Agreed, 2007; Goetz, 1995). Support for the communal discernment approach is also found in the theological work of de Villiers, who has suggested that communal discernment is actually the biblical approach to handling controversy, as can be seen in Acts 15 in a debate regarding whether circumcision was a required sign of salvation (de Villiers, 2013).

Finally, Strauch (1995), in his study of biblical church leadership, suggested that the church return to a decision-making model based on qualified and shared pastoral leadership. He noteed that the biblical principle the apostles exhibited was "first among equals." This was the principle demonstrated by Peter's leadership; it was based on the works of a servant rather than pursuit of a title or yearned-after position.

\section{THE STUDY}

This project sought to understand the extent of cognitive fixation and the presence of fixating factors within the processes of pastoral thinking and decision-making. Also, this work sought insight into how cognitive fixation and fixating factors such as expertise and previous experience might occur in pastors' thinking and decisionmaking.

The following research questions guided this study:

1. To what extent is cognitive fixation a part of pastors' thinking and decision-making processes?

2. What types of cognitive fixation-related factors exist in pastors' thinking and decision-making processes?

Though the primary focus of this study was pastors' thinking and decision-making processes, the research also explored personal and group factors influencing leadership choices.

\section{METHOD}

Qualitative inquiry was selected for this research because it facilitates the discovery and understanding of underexplored psychological phenomena (Willig, 2013). Thematic analysis of the narratives, as a way of discovering themes or patterns within data (Boyatzis, 1998; Daly, Kellehear, \& Glicksman, 1997), was used as an analytical research method because it helped to bring understanding through "the ways in which people make and use stories to interpret the world" (May, 2002). Thematic analysis was also used to examine the "hows" and "whys" of decisionmaking (Braun \& Clarke, 2006).

\section{PARTICIPANTS}

In this purposive sampling, participants were selected from a pool of pastors from Protestant denominational churches in Texas. Pastors chosen for this study led congregations consisting of a minimum of 50 members and a maximum of 1,800 members, and had served in a full-time position for at least five years in at least one church. Table 1 describes the demographics and respective church sizes of the participating pastors. The choice to use pastors of smaller congregations was made in an effort to increase consistency; the particular dynamics of megachurches may differently affect pastoral decision-making. In addition, congregation size is a factor in how pastors 
interact with their worshipers and lay leadership teams. In smaller congregations, preaching and pastoral roles are emphasized by activities such as visiting the sick; however, as congregations increase in size, pastors tend to focus more on sermons, vision casting, and strategy (Keller, 2008).

The criterion of five years of experience was used because pastors often leave their ministries within a five-year period (Francis A. Schaeffer Institute of Church Leadership Development, 1998). In addition, pastors can acquire important expertise in five years and expertise may influence decision-making, as suggested by previouslymentioned studies on cognitive fixation (Wiley, 1998; Smith, 1994; 2010). Other studies on expertise (Palmer, Stough, Burdenski, \& Gonzales, 2005) also used a five-year minimum of experience as a criterion. Additional research on the impact of pastoral experience on ministerial priorities (e.g., Stevens, Loudon, \& Paschal, 1996) has suggested that pastors with extensive experience $(50 \%$ of the participants in that study had more than 15 years' experience) show less interest in understanding missions and general church potential. It was suggested that experienced pastors are more likely to focus on the inward needs of the congregation than are pastors serving for shorter periods of time.

This study focused on the experiences of ten pastors chosen from different denominations, genders, ethnic groups, and levels of experience.

Table 1: Demographics of Participants

\begin{tabular}{|ccccccc|}
\hline $\begin{array}{c}\text { Pseudonym } \\
\text { (Gender) }\end{array}$ & $\begin{array}{c}\text { Self-reported } \\
\text { ethnicity }\end{array}$ & $\begin{array}{c}\text { Number of } \\
\text { years } \\
\text { pastoring }\end{array}$ & $\begin{array}{c}\text { Number of } \\
\text { churches } \\
\text { served }\end{array}$ & Age & $\begin{array}{c}\text { Church } \\
\text { Size }\end{array}$ & Denomination \\
Malcolm (M) & White & 5 & 2 & 38 & 200 & Presbyterian \\
Paul (M) & White & 5 & 2 & 38 & 80 & Pentecostal \\
Charles (M) & White & 6 & 2 & 33 & 100 & Presbyterian \\
George (M) & White & 11 & 1 & 38 & 1800 & Independent \\
Landan(M) & White & 12 & 1 & 46 & 225 & Pentecostal \\
Victor (M) & White & 15 & 2 & 58 & 1100 & Methodist \\
Michael (M) & White & 15 & 3 & 50 & 50 & Baptist \\
Sandra (F) & White & 19 & 3 & 52 & 600 & Episcopalian \\
Stuart (M) & African American & 20 & 2 & 48 & 240 & Methodist \\
Timothy (M) & White & 28 & 5 & 56 & 400 & Methodist \\
\hline
\end{tabular}

\section{PROCEDURE}

\section{Semi-Structured Interviews}

Interviews with each participant were conducted face-to-face in the interviewees' church offices or at an external location. In eight of the interviews, offices were selected as the venue as a matter of convenience, because it was a private space that facilitated communication. However, two pastors preferred to meet outside the church, at coffee shops. Interruptions occurred during these two interviews, but they did not affect the quality of the experience. Each interview lasted approximately 90 minutes, and used an interview protocol as the basis for inquiry. The semistructured interview format allowed participants to go beyond the initial interview questions, into what Rubin and Rubin (1995) described as extended conversations and conversational partnerships. In these interviews, pastors felt free to offer additional information and ask questions of the researcher. The researcher suggested finishing all interviews with a prayer for the church and pastor involved. Those prayers were welcomed by all of the pastors.

The interviews were recorded using a digital audio recording device. After each interview was transcribed, it was shared with participants for their review, in order to ensure the accuracy of the content. Field notes were taken during and immediately after the interviews so that non-verbal activity could be recorded. Follow-up communication with all participants was conducted through email. Subsequent contact was initiated to clarify content, gather additional insights, and ask questions that the research process and reflexive journal generated. Subjects included data about the 
size of the church, biographical data about the participant, and interviewees' precise involvement in decision-making regarding financial issues. Using email for this purpose provided time and flexibility for the participant to answer the questions, as well as a record that could be used as a source of additional data.

\section{Meeting Observations}

The purpose of observing pastoral decisionmaking behaviors during administrative meetings was to clarify and support the data previously acquired through the interviews. Eight out of the 10 pastors included lay leaders in the administrative meetings conducted on church premises. Two pastors declined to allow the researcher to observe. Meetings lasted two hours and were attended by an average of eight lay leaders each. In some meetings, the pastor presented church progress, including results obtained through recent church activities. In other meetings, the pastor acted as a facilitator to help the flow of decisions made by the group.

\section{Data Analysis}

Data gathered from the interviews and meeting observations were analyzed using the constant comparative method suggested by Glaser and Strauss (1967). In addition, Miles and Huberman's (1994) systematic processes were used, including writing margin notes in the fieldnotes (such as comments on pastors' reflections). Other processes included writing reflections in a reflexive journal on larger themes that the participants addressed in the interviews, and noting patterns and themes.

Data were unitized systematically. First, the researcher identified discrete ideas from the interview transcripts, observational notes, and documents. Unitizing helped to break the information down into small units that stood alone in the absence of additional information (Lincoln \& Guba, 1985). Trustworthiness in this study was established through the use of triangulation, peer debriefing, and member checking (Creswell, 2013; Lincoln \& Guba, 1985). After all of the data were analyzed, three clear themes emerged regarding fixation. The first revealed a more complex reality than had been suggested in the literature. The second recommended that cognitive fixation did indeed play a role in how these pastors perceived challenges. The third illustrated how special circumstances helped many pastors overcome cognitive fixation.

\section{Themes}

Emergent Theme 1: Cognitive fixation in pastoral decision-making involves more stakeholders than just the pastor, and is heavily influenced by the concepts of clergy and laity.

The first theme that emerged from the participants' comments, observations, and insights was how cognitive fixation in the church impacted more of the key stakeholders than just the pastor. It was experienced by both leaders and the congregation, in different ways. Church structures delimited the types of decisions the pastors made. Some pastors belonged to denominational churches governed by a committee structure that included checks and balances, and which served to delimit the pastors' decision-making power. For instance, in one meeting one pastor disagreed with a decision that was made regarding the choice of movie for a Christmas event, but he stated that he would "not step outside my boundaries." This revealed that cognitive fixation in decision-making was occurring at a level beyond that of the pastor. Other incidences indicated that lay leaders and congregants also experienced cognitive fixation in the ways they learned, ministered, participated in decision-making processes, experienced worship, and performed outreach activities.

Since lay leaders were entrusted with decisionmaking powers, their willingness to learn and improve determined whether they would move beyond their current state, to one that would advance their ministries. For instance, one pastor confided that some leaders would refuse to administer communion outside of the church, even though they did administer it in the church:

For the leadership level, [it was important to take] communion to our homebound members, persons who are unable to get to worship and relay any given time. They're just ... their mobility is too low. Their mind is often very sharp, but they're unable to come to worship. And so bringing what we call a Holy Feast of the Lord's Supper to them, to their house, I had several other leaders, the ruling elders, they're like, 'No. I'm not going to do that. I'm uncomfortable doing that.' 
Another pastor noticed a pattern in his many years of ministry regarding congregants' openness to change. "Apparently, the older we get, the less we like it. That's been something that I've seen in my ministry." In fact, age has indeed been shown to be a factor in mental rigidity (Rhodes, 2004).

Cognitive fixation in membership was also apparent in another church. A few members insisted on attending a prayer meeting at 6:30 am in the morning, even though the attendance had decreased significantly in the previous few years. The pastor felt that he could not change anything because it "would break their heart[s]." A similar mindset was found in a different church where even members were wary of pastoral ministry visits. They could not understand why leaders of the church would visit them in hospital. In yet another church, leaders were surprised that the pastor would ask them for their input in decision-making because they had been trained not to question pastoral authority. The leaders assumed that their opinions did not count. Several pastors had to train them to express their opinions on church matters. Regarding worship services, several congregations had become fixated on certain ways of conducting church services; even small changes were not accepted. For instance, one congregation was dismayed at a pastor's choice not to include a certain song (Silent Night) as the last of the Christmas service. Another congregation could not accept having a church service on Saturdays.

Many pastors also recognized that a type of groupthink tended to happen in church. This occurred when under certain circumstances, such as when a charismatic leader was present, the group dynamics caused the group to fixate on the leader's idea without examining possible alternatives (Janis, 1972). A group is most vulnerable to this type of thinking when it is protected from outside opinions, and when the group members share similar backgrounds and experiences (Janis, 1972). One pastor stated that it "happens all the time." He tried to avoid it by waiting before his decision was made, and praying about it. He asked questions based on his "personality and experience" to uncover hidden reasons for disagreements. $\mathrm{He}$ added: "I gave recognition and honor to the person that didn't think like everybody else." He believed that groupthink happened in his church "and every church ... even healthy churches." He discovered in a very short time that there were people who were "ineffective and dysfunctional" but "popular and influential," and their "opinion [held]." $\mathrm{He}$ added that most pastors were not equipped to deal with groupthink; "they don't have the tool[s] and they don't have the spiritual and emotional resources to know how to deal with that kind of conflict." This pastor admitted that his way of dealing with groupthink was "hardly ever satisfactory to people in the church, because people in the church want to win. They do not want to win an argument; they want to win ... American culture is about winning."

Mental automaticity can also be seen in the type and manner of ministries carried out over the years. Some programs continued long after they ceased to be useful. In mental automaticity, individuals are unable to break from the traditional patterns or ways of solving problems, even though the underlying elements of the problem may have changed (Bilalić et al., 2010; Luchins, 1942). For instance, one pastor recognized that the congregation had been fixated on the way the church had run certain projects, such as the Thanksgiving program; he decided to stop holding the event because it was no longer meeting the needs of the community. He recognized that the church needed to build relationships rather than simply hand out meals.

Another pastor discussed two different "tried and tested" outreach activities that offered little in the way of results. His solution seemed to have been influenced by prior knowledge and expertise (Smith, 2003; Wiley, 1998). His church promoted a children's program without doing any research on the number of children living in the neighborhood. The result was that no children showed up for their event. Other pastors shared anecdotes about congregants who held on to traditions without understanding the reasons for them. One included giving a clam shell with a scripture passage on it to a child after they'd been baptized. When the congregants questioned why the pastor stopped the practice, he asked them to explain the motivation behind the gift; they could not come up with a response.

Emergent Theme 2: Cognitive fixation plays a role in how pastors perceive challenges.

The second theme that emerged from this analysis was that cognitive fixation seems to play a role in how pastors perceive church-related 
challenges. When asked about the greatest trials they faced, many pastors quickly referred to issues involving church buildings and finances. Smaller churches tended, over the years, to focus on buildings; larger churches faced similar challenges, due to an unanticipated increase in the number of members. Most pastors tended to emphasize this and other concrete financial issues such as budgets, fund raisers, and attendance. Some also focused on the importance of a quick elimination of financial burdens generated by church buildings key to the organization's survival. As one pastor put it, "literally the church was going to close in a couple of years if it didn't get rid of that property, because of the debt service on that property." One pastor stated, "the greatest thing that we have to be ... as a pastor is [someone who is] building faith and building strength and a spiritual relationship with God." Another offered a different perspective, regarding buildings:

I think building, putting a lot of money into buildings, church buildings, is something we've also done and it's a tradition, but not necessarily the most effective way to reach people with it for the Kingdom of God...Why would you put $\$ 4$ million in a building that's only used once a week when you could be [in] a building that could become a community gathering place?

Intangible issues such as spiritual development did not arise as often. When the topic did emerge, pastors did not develop strategies or measurements of success.

Other pastors, when discussing financial issues, focused on fund raising activities and finding new ways to get people to tithe and make other offerings. One reasoned that an effort had to be made to educate members about the importance of giving to the church because "about $20 \%$ of the congregation will do about $80 \%$ of the work and $80 \%$ of the giving." In this interview, one pastor of a small church focused on church financial issues, explaining that the congregants did not know about giving and had an expectation that the church would provide for them; this was because most were from low-income families.

Church culture often determines the way challenges are perceived. This environment is rich in preconceptions and biases that affect how decisions are made (Sassenberg \& Moskowitz, 2005; Rudman, Ashmore, \& Gary, 2001). It is a pastor's job to be aware of the spiritual needs of the congregation, but when describing the challenges, they faced in maintaining their respective churches, the pasters interviewed for this research tended to fixate on tangible issues such as buildings, finances, and attendance (rather than the intangible, spiritual issues of the congregation).

Kaiser's suggestion regarding growing from one tangible paradigm can be seen in the question: "Has the congregation been growing numerically?" Traces can also be found in the more intangible paradigm represented by the question: "Has this growing, evangelistic, reproducing, globally missional, biblically faithful congregation been seeking the face of God in all that it does?" (Kaiser, 2011). Pope corroborates this church position, suggesting that the purpose and success of the church is not found in its number of members, size of its staff, or scope of its budget, but rather in the more intangible level of transformation seen in the community the church serves (Pope, 2006).

Emergent Theme 3: Peculiar challenges in special church circumstances helped pastors overcome their cognitive fixation.

A third theme emerged from the data analysis. Most pastors had a unique story to tell about peculiar circumstances that helped them think beyond their experiences and area of expertise, and thus overcome a particular fixation. These special circumstances created the space for leadership to emerge, a greater impact to be made by the elders of the church (Nehrbass, 2011), and the church to mature and better fulfil its role in the community. When one pastor suffered the loss of several key spiritual leaders, other members stepped in to help.

But at that meeting, I had people step up out of loyalty and out of ... discernment would be the right word ... out of discernment of what was really happening. I had people step up and say, 'I will take care of the music until you tell me otherwise' or 'I will take care of the young people for now.'

He went on to reflect on the results of those decisions: 
Believe it or not, every one of those leaders stepped up at that time. Now, three and a half years later, most of them - if not all of them - are still in those roles, still trucking along doing exactly what they were intended to do and expected to do and intended in their own hearts. The church has grown.

He explained that he used the term "grown" to mean greater stability and stronger leadership. For him, those were signs of a spiritual growth that moved beyond tangible issues.

Another pastor described how his predecessor had frequently been absent, spending his time at different locations. That created the space for lay leaders to emerge and take leadership positions in different ministries such as interfaith groups, a free legal clinic for illegal immigrants, and Habitat for Humanity projects providing homes to low-income families. He also commented that in his experience, the flexible nature of the local church was unusual.

Unique circumstances in another pastor's church helped him to cope with the death of an experienced pastor who had been hired to help him manage the church. The congregation had to step in to assist. In describing the situation, he said: "In the first years, especially when my executive pastor was diagnosed with cancer, most of the actual dayto-day ministry was not from staff. It was through the congregation, because they really had to step up and help me when there was that need, and they did. They were there." Another key factor was the accelerated growth in the number of members, but not in finances, which he recognized as beneficial. These two events forced the church to live out their mission of empowering leaders.

Pastors will benefit from understanding these three themes in the following ways. First, it is important for them to strive to overcome cognitive fixation in lay leaders and congregants who hinder the church from providing meaningful service to society. Second, pastors should become more aware of how they perceive challenges and focus on developing intangible assets (that is, the spiritual development of the leaders and members in the church), so that they can become agents of change. This shift in focus willould affect the emphasis given to tangible facts such as church buildings and the number of rooms and facilities in the church. Third, pastors would be better equipped to recognize change and adversity as a catalyst for change in people's ways of thinking. An awareness of this progression would help them to engage in a metacognitive process in which they could clearly identify and overcome their own cognitive fixation.

\section{IMPLICATIONS FOR PRACTICE}

The results of this study and the emergent themes raised some challenges to the conceptualization of pastoral thinking. For instance, should the Church be considered a permanent or changing institution? Should pastors focus their attention on worship services and activities in the church building or support the congregation to carry the concept of church with them as they live outside of its walls? The concept of functional fixedness may apply to pastors' implicit definitions of the Church in that they may see it as a stable, unchanging organization, rather than one that is flexible, given the needs of society. Other factor that may influence pastoral decisionmaking is how pastors view the purpose of the church. If it is viewed as a place that should receive as many people as possible, then pastors will focus on building larger structures as it grows. However, if pastors see the church as a place to train people who send to do works of service in the community, then the emphasis would be to train, equip and empower those members for that work.

Pastors in this study sometimes found a way to overcome cognitive fixation. . The need for pastors to become aware of their own thinking processes in leading churches has already been documented (The Barna Group, 2006; Kinnaman, 2011). As cognitive fixation is difficult to detect it may be useful for pastors to engage in the development of metacognitive abilities such as problem formulation and ideation, that will help them to overcome stubborn cognitive fixations. Such training has already been recommended for use in the medical field (Croskerry, 2002). Another solution might be to make training in creativity and flexible leadership part of ministry education.

The results of this study also illustrate the relationship between personal cognitive fixation and group cognitive fixation at the leadership and congregational levels; consequently, pastors will benefit from understanding systems thinking. Pastors are part of a system that interacts with other groups such as lay leaders and congregants. Mental 
models assist in clarifing internal pictures of the world and how they shape actions and decisions (Senge, 2006). Such practices also enhance team building, as they are based on deep listening, empowerment, and a shared vision. However, successful training in these areas depend on a flexible mindset. Pastors are more likely to embrace a growth mindset if they believe in the importance of personal improvement and change (Dweck, 2006).

Finally, pastors will benefit from communicating with one another about changes they have made to their thinking and decisionmaking processes. Moreover, pastors can further their progress in this area by finding ways to reinvent the church experience so that it provides fresh solutions to society's changing needs (McLaren, 1998). Examples of such new approaches can be found in the innovation literature on understanding customers' needs (Ulwick, 2005), deeply empathizing with customers (Brown, 2008), and designing marketplace modernizations (Kim \& Maubourgne, 2005).

\section{REFERENCES}

[1] Adelson, B. (1984). When novices surpass experts: The difficulty of a task may increase with expertise. Journal of Experimental Psychology: Learning, Memory, and Cognition, 10(3), 483-495. https://doi.org/10.1037/0278-7393.10.3.483

[2] Alex-Assensoh, Y. M. (2004). Taking the sanctuary to the streets: Religion, race, and community development in Columbus, Ohio. The Annals of the American Academy of Political and Social Science, 594(1), 79-91. https://doi.org/10.1177/0002716204264781

[3] The Barna Group. (2006). Surveys show pastors claim congregants are deeply committed to God but congregants deny it!

[4] Barnes, S. L. (2011). Black megachurches: Social gospel usage and community empowerment. Journal of African American Studies, 15(2), 177-198. https://doi.org/10.1007/s12111-010-9148-8

[5] Bilalić, M., McLeod, P., \& Gobet, F. (2008). Why good thoughts block better ones: The mechanism of the pernicious Einstellung (set) effect. Cognition, 108(3), 652-661. https://doi.org/10.1016/j.cognition.2008.05.005

[6] Bilalić, M., McLeod, P., \& Gobet, F. (2010). The mechanism of the Einstellung (set) effect: A pervasive source of cognitive bias. Current Directions in Psychological Science, 19(2), 111-115. https://doi.org/10.1177/0963721410363571

[7] Boyatzis, R. E. (1998). Transforming qualitative information: Thematic analysis and code development. Thousand Oaks, CA: Sage. Retrieved from https://us.sagepub.com/en-us/nam/transforming-qualitativeinformation/book 7714

[8] Braun, V., \& Clarke, V. (2006). Using thematic analysis in psychology. Qualitative Research in Psychology, 3(2), 77-101. https://doi.org/10.1191/1478088706qp063oa

[9] Brown, T. (2008). Design thinking. Harvard Business Review, 86(6), 84. https://hbr.org/2008/06/designthinking 
[10] Callahan, K. (1983) Twelve keys to an effective church: Strategic planning for mission. San Francisco: Harper \& Row.

[11] Carroll, J. W. (2006). God's potters: Pastoral leadership and the shaping of congregations. Gran Rapids, MI: Wm. B. Eerdmans Publishing.

[12] Chase, W.A., \& Simon, H. A. (1973). Visual information processing. W. G. Chase (Ed). New York: Academic Press. 215-281.

[13] Chrysikou, E. G., \& Weisberg, R. W. (2005). Following the wrong footsteps: Fixation effects of pictorial examples in a design problem-solving task. Journal of Experimental Psychology: Learning, Memory, and Cognition, 31(5), 1134. https://doi.org/10.1037/0278-7393.31.5.1134

[14] Creswell, J. W. (2013). Research design: Qualitative, quantitative, and mixed methods approaches. Sage publications. Croskerry, P. (2002). Achieving quality in clinical decision-making: Cognitive strategies and detection of bias. Academic Emergency Medicine, 9(11), 1184-1204.

[15] Daly, J., Kellehear, A., \& Gliksman, M. (1997). The public health researcher: A methodological approach. Melbourne, Australia: Oxford University Press. 611-618.

[16] De Villiers, P. G. (2013). Communal discernment in the early Church. Acta Theologica, 33, $132-155$. https://doi.org/10.4314/actat.v32i2s.8

[17] Dearman, D. T., \& Shields, M. D. (2005). Avoiding accounting fixation: Determinants of cognitive adaptation to differences in accounting method. Contemporary Accounting Research/Recherche Comptable Contemporaine, 22(2), 351-384. https://doi.org/10.1506/rq40-ur50-5crl-yu8a

[18] Dever, M. (2004). Nine marks of a healthy church. Wheaton, IL: Crossway Books.

[19] Dweck, C. (2006). Mindset: The new psychology of success. New York: Random House.

[20] Evans, R. H. (2013). Why millennials are leaving the church. Retrieved from http://religion.blogs.cnn.com/2013/07/27/why-millennials-are-leaving-the-church/

[21] Francis A. Schaeffer Institute of Church Leadership Development (1998). Statistics on Pastors. Retrieved from http://www.churchleadership.org/apps/articles/default.asp? articleid=42347\&columnid=4545

[22] Frykholm, A. J., Churches, C., \& Agreed, I. (2007). Out of silence: The practice of congregational discernment. Christian Century, 124, 7.

[23] Glaser, B. G., \& Strauss, A. L. (1967). The discovery of grounded theory: Strategies for qualitative research. Chicago, IL: Aldine. Retrieved from http://www.sxf.uevora.pt/wpcontent/uploads/2013/03/Glaser_1967.pdf

[24] Goetz, D. (1995). Helping your board listen to God: Breaking out of the routine for better decisions. Leadership, 16, 47.

[25] Graber, M. L., Franklin, N., \& Gordon, R. (2005). Diagnostic error in internal medicine. Archives of Internal Medicine, 165(13), 1493. https://doi.org/10.1001/archinte.165.13.1493

[26] Granström, K., \& Stiwne, D. (1998). A bipolar model of groupthink: An expansion of Janis's concept. Small Group Research, 29(1), 32-56. https://doi.org/10.1177/1046496498291002

[27] Hinds, P. J. (1999). The curse of expertise: The effects of expertise and debiasing methods on prediction of novice performance. Journal of Experimental Psychology: Applied, 5(2), 205. https://doi.org/10.1037/1076$\underline{898 \times .5 .2 .205}$

[28] Hinds, P. J., Patterson, M., \& Pfeffer, J. (2001). Bothered by abstraction: The effect of expertise on knowledge transfer and subsequent novice performance. Journal of Applied Psychology, 86(6), 1232. https://doi.org/10.1037/0021-9010.86.6.1232

[29] Hougland, J. G., \& Wood, J. R. (1979). "Inner circles" in local churches: An application of Thompson's theory. Sociology of Religion, 40(3), 226-239. https://doi.org/10.2307/3710240

[30] Janis, I. L. (1972). Victims of groupthink: A psychological study of foreign-policy decisions and fiascoes. Boston, MA: Houghton Mifflin Company. https://doi.org/10.1163/2468-1733_shafr_sim010150024

[31] Jansson, D. G., \& Smith, S. M. (1991). Design fixation. Design Studies, 12(1), 3-11. https://doi.org/10.1016/0142-694x(91)90003-f

[32] Johnson, L. T. (1996). Decision-making in the Church: A biblical model. Nashville, TN: Abingdon Press. https://digitalcommons.pepperdine.edu/cgi/viewcontent.cgi?article=2134\&context=leaven

[33] Kaiser. J. E. (2011). Fish or cut bait: How winning churches make decisions. Nashville, TN: Abingdon Press.

[34] Keller, T. (2008). Process managing church growth: How strategy changes over time. Cutting Edge Magazine, 11(2), 5-10.

[35] Kinnaman, D. (2011). You lost me: Why young Christians are leaving church...and rethinking faith. Grand Rapids, MI: Baker Books. 
[36] Kinnaman, D. (2011). You lost me: Why young Christians are leaving church....and rethinking faith. Grand Rapids, MI: Baker Books.

[37] Kim, W. C., \& Mauborgne, R. (2005). Blue ocean strategy: From theory to practice. California Management Review, 47(3), 105-121. https://doi.org/10.2307/41166308

[38] Lincoln, Y. S., \& Guba, E. (1985). Naturalistic inquiry. Newbury Park, CA: Sage Publications.

[39] Linsey, J., Tseng, I., Fu, K., Cagan, J., Wood, K., \& Schunn, C. (2010). A study of design fixation, its mitigation and perception in engineering design faculty. Journal of Mechanical Design, 132(4), 041003. doi:10.1115/1.4001110. https://doi.org/10.1115/1.4001110

[40] Luchins, A. S. (1942). Mechanization in problem solving: The effect of Einstellung. Psychological monographs, 54(6), i-95. https://doi.org/10.1037/h0093502

[41] Luchins, A. S., \& Luchins, E. H. (1959). Rigidity of behavior: A variational approach to the effect of Einstellung. Eugene, OR: University of Oregon Books. https://doi.org/10.2307/1419434

[42] Marchant, G., Robinson, J., Anderson, U., \& Schadewald, M. (1991). Analogical transfer and expertise in legal reasoning. Organizational Behavior and Human Decision Processes, 48(2), 272-290. https://doi.org/10.1016/0749-5978(91)90015-1

[43] Macchia, S. (1999). Becoming a healthy church: 10 characteristics. Grand Rapids, MI: Baker Books.

[44] May, T. (2002). Qualitative research in action. London, UK: Sage Publications.

[45] McLaren, B. D. (1998). Reinventing your church. Grand Rapids, MI: Zondervan.

[46] Miles, M. B., \& Huberman, A. M. (1994). Qualitative data analysis: An expanded sourcebook. London, UK: Sage Publications.

[47] Nauss, A. (1995). The pastor as leader: Shepherd, rancher, or...? Journal of Psychology and Theology, 23(2), 115-128. https://doi.org/10.1177/009164719502300204

[48] Nauta, R. (1988). Task performance and attributional biases in the ministry. Journal for the Scientific Study of Religion, 27(4), 609-620. https://doi.org/10.2307/1386952

[49] Nehrbass, D. (2011). A biblical model of church decision-making. Lexington, KY: CreateSpace Independent Publishing Platform.

[50] Öllinger, M., Jones, G., \& Knoblich, G. (2008). Investigating the effect of mental set on insight problem solving. Experimental Psychology, 55(4), 269. https://psycnet.apa.org/doi/10.1027/1618-3169.55.4.269

[51] Palmer, D. J., Stough, L. M., Burdenski, Jr., T. K., \& Gonzales, M. (2005). Identifying teacher expertise: An examination of researchers' decision making. Educational Psychologist, 40(1), 13-25.

[52] Patel, V. L., \& Groen, G. J. (1991). The general and specific nature of medical expertise: A critical look. Toward a general theory of expertise: Prospects and limits, 93-125.

[53] Pope, R. (2006). The intentional church: Moving from church success to community transformation. Chicago, IL: Moody Publishers. Retrieved from https://www.moodypublishers.com/the-intentional-church/

[54] Primeaux. P. (1997). The emperor unclothed: "Groupthink" in pastoral decision-making. Journal of Ministry Marketing \& Management, 3(1), 33-47. https://doi.org/10.1300/j093v03n01_03

[55] Puccio, G. J., Mance, M., \& Murdock, M. C. (2010). Creative leadership: Skills that drive change. Sage Publications. Retrieved from https://onlinelibrary.wiley.com/doi/abs/10.1111/j.1467-8691.2008.00468.x

[56] Purcell, A. T., \& Gero, J. S. (1996). Design and other types of fixation. Design Studies, 17(4), 363-383. https://doi.org/10.1016/s0142-694x(96)00023-3

[57] Redelmeier, D. A., Ferris, L. E., Tu, J. V., Hux, J. E., \& Schull, M. J. (2001). Problems for clinical judgement: Introducing cognitive psychology as one more basic science. Canadian Medical Association Journal, 164(3), 358-360. https://www.ncbi.nlm.nih.gov/pmc/articles/PMC80731/

[58] Rhodes, M. G. (2004). Age-related differences in performance on the Wisconsin card sorting test: A metaanalytic review. Psychology and Aging, 19(3), 482. https://doi.org/10.1037/0882-7974.19.3.482

[59] Rosander, M., Granström, K., \& Stiwne, D. (2006). Group mind in Christian communities. Nordic Psychology, 58(1), 74. https://doi.org/10.1027/1901-2276.58.1.74

[60] Rubin, H. J., \& Rubin, I. S. (1995). Qualitative interviewing: The art of hearing data. Thousand Oaks, CA: Sage. $\quad$ Retrieved from https://www.scirp.org/(S(1z5mqp453edsnp55rrgjct55))/reference/ReferencesPapers.aspx?ReferenceID=137 $\underline{9117}$

[61] Rudman, L. A., Ashmore, R. D., \& Gary, M. L. (2001). "Unlearning" automatic biases: The malleability of implicit prejudice and stereotypes. Journal of Personality and Social Psychology, 81(5), 856. https://doi.org/10.1037/0022-3514.81.5.856 
[62] Sassenberg, K., \& Moskowitz, G. B. (2005). Don't stereotype, think different! Overcoming automatic stereotype activation by mindset priming. Journal of Experimental Social Psychology, 41(5), 506-514. https://doi.org/10.1016/j.jesp.2004.10.002

[63] Schwarz, C. A (2003). Natural church development: A guide to eight essential qualities of healthy churches. Carol Stream, IL: ChurchSmart Resources. Retrieved from https://www.amazon.com/Natural-ChurchDevelopment-Essential-Qualities/dp/1889638005

[64] Senge, P. M. (2006). The fifth discipline: The art and practice of the learning organization. New York, NY: Doubleday.

[65] Smith, S. M. (2010). Blocking out blocks. In A. Benjamin (Ed.) Successful Remembering and Successful Forgetting: A Festschrift in Honor of Robert A. Bjork. New York, NY: Psychology Press. 153. https://experts.illinois.edu/en/publications/successful-remembering-and-successful-forgetting-a-festschriftin

[66] Smith, S. M. (1994). Getting into and out of mental ruts: A theory of fixation, incubation, and insight. In R. J. Sternberg \& J. Davidson (Eds.) The Nature of Insight. Cambridge, MA: MIT Press. 121-149. https://doi.org/10.7551/mitpress/4879.003.0011

[67] Smith, S. M., \& Blankenship, S. E. (1991). Incubation and the persistence of fixation in problem solving. The American Journal of Psychology, 104(1), 61-87. https://doi.org/10.2307/1422851

[68] Smith, S. M., \& Linsey, J. (2011). A three-pronged approach for overcoming design fixation. The Journal of Creative Behavior, 45(2), 83-91. https://doi.org/10.1002/j.2162-6057.2011.tb01087.x

[69] Smith, S. M., Linsey, J., \& Kerne, A. (2010). Using evolved analogies to overcome creative design fixation. Paper presented at the Proc International Conference on Design Creativity (ICDC), 35-40.

[70] Smith, S. M. (2003). The constraining effects of initial ideas in group creativity: Innovation through collaboration. Paul B. Paulus \& B. Nijstad (Eds.) Oxford University Press. https://doi.org/10.1093/acprof:oso/9780195147308.003.0002

[71] Stevens, R. E., Loudon, D. L., \& Paschal Jr., R. W. (1996). A survey of pastors' continuing education needs in leadership and management skills. Journal of Ministry Marketing \& Management, 2(1), 71-79. https://doi.org/10.1300/j093v02n01_06

[72] Strauch, A. (1995). Biblical eldership. Littleton, CO: Lewis and Roth. https://doi.org/10.2172/212507

[73] Ulwick, A. W. (2005). What customers want: Using outcome-driven innovation to create breakthrough products and services. New York: McGraw-Hill.

[74] Vallée-Tourangeau, F., Euden, G., \& Hearn, V. (2011). Einstellung defused: Interactivity and mental set. The Quarterly Journal of Experimental Psychology, 64(10), 1889-1895. https://doi.org/10.1080/17470218.2011.605151

[75] Verhaeghen, P., Marcoen, A., \& Goossens, L. (1993). Facts and fiction about memory aging: A quantitative integration of research findings. Journal of Gerontology, 48(4), 157-171. https://doi.org/10.1093/geronj/48.4.p157

[76] Viswanathan, V., \& Linsey, J. (2013). Examining design fixation in engineering idea generation: The role of example modality. International Journal of Design Creativity and Innovation, 1(2), 109-129. https://doi.org/10.1080/21650349.2013.774689

[77] Wallau, L. \& Johnson, B. (2013). Invading Babylon: The 7 mountain mandate. Shippensburg, PA: Destiny Image.

[78] Ward, T. B., Smith, S. M., \& Vaid, J. (Eds.). (1997). Creative thought: An investigation of conceptual structures and processes. Washington, DC: American Psychological Association. https://doi.org/10.1037/10227-000

[79] Wiley, J. (1998). Expertise as mental set: The effects of domain knowledge in creative problem solving. Memory \& Cognition, 26(4), 716-730. https://doi.org/10.3758/bf03211392

[80] Willig, C. (2013). Introducing qualitative research in psychology. Berkshire, England: McGraw-Hill Education.

[81] Youmans, R. J., \& Arciszewski, T. (2012). Design fixation: A cloak of many colors. In Proceedings of the 2012 Design, Computing, and Cognition Conference, College Station, Texas.

Received on 10-02-2021

Accepted on 20-02-2021

Published on 29-02-2021

(c) 2021 Hector Ramos and Joyce Juntune; Licensee ATSK Publishers.

This is an open access article licensed under the terms of the Creative Commons Attribution Non-Commercial License (http://creativecommons.org/licenses/by-nc/3.0/) which permits unrestricted, noncommercial use, distribution and reproduction in any medium, provided the work is properly cited. 